Gut, 1989, 30, 1392-1395

Liver, biliary and pancreas

\title{
Plasma leucine enkephalin is increased in liver disease
}

\author{
J R THORNTON AND M S LOSOWSKY \\ From the Department of Medicine, St James's University Hospital, Leeds
}

\begin{abstract}
SUMMARY Plasma methionine enkephalin is increased in liver disease and may contribute to some of the clinical manifestations of hepatic failure. To determine if another 'small' opioid peptide is increased in the plasma of patients with liver disease, leucine enkephalin was measured by radioimmunoassay. Its plasma concentration was raised approximately five-fold in patients with acute liver disease (median $1490 \mathrm{pmol} / \mathrm{l}$, range 830-2420) and three-fold in patients with cirrhosis with ascites (960 pmol//, 470-2900), compared with disease controls $(325 \mathrm{pmol} / \mathrm{l}, 180-740)$ and healthy controls $(305 \mathrm{pmol} / \mathrm{l}, 180-560)$. The increase in plasma leucine enkephalin was proportional to the degree of liver damage, as judged in the patients with acute liver disease by its correlation with the prothrombin time $(r=0.691, p<0 \cdot 01)$ and alanine aminotransferase $(r=0.502, p<0.05)$, and in the patients with cirrhosis by its negative correlation with the plasma albumin $(r=-0 \cdot 743$, $\mathbf{p}<\mathbf{0 \cdot 0 0 1 )}$. It is unclear whether the raised plasma leucine enkephalin in liver disease is a consequence of diminished hepatic inactivation, increased secretion from sympathetic nerves and adrenal glands, or both.
\end{abstract}

The liver may play a major role in the elimination of blood borne opioid peptides of octapeptide size or less.' In favour of this hypothesis, the pentapeptide methionine enkephalin ${ }^{2}$ but not the much larger opioid peptide, $\beta$-endorphin, ${ }^{3}$ is increased in liver disease. Raised plasma levels of some opioid peptides may contribute to some of the clinical manifestations of hepatic failure. This possibility is indicated by the recent finding that administration of an opioid antagonist, nalmefene, to patients with primary biliary cirrhosis produced an opioid withdrawal reaction, alleviated their pruritus and fatigue, and reduced their plasma bilirubin. ${ }^{4}$

Five other opioid peptides comprising eight or fewer amino acids are known (methionine enkephalin-arg-phe, methionine enkephalin-arg-gly-leu, leucine enkephalin, adrenorphin and dynorphin 1-8). If the hypothesis of predominant hepatic elimination of these peptides is correct, they may be found to be raised in the plasma of patients with liver disease. Therefore, we have investigated whether this is the case for one such peptide, leucine enkephalin (tyrgly-gly-phe-leu).

Address for correspondence: Dr J R Thornton, Dept of Medicine, St James's Hospital, Leeds LS9 7TF.

Accepted for publication 9 February 1989.
Methods

SUBJECTS

Six groups, each comprising 15 subjects, were studied: (i) Acute liver disease: 12 caused by paracetamol overdose and three by hepatitis A. Seven of these patients had hepatic encephalopathy but none had a markedly raised plasma creatinine at the time of blood sampling (Table). Three patients in this group subsequently died of liver failure. (ii) Cirrhosis with ascites: the presence of ascites was confirmed by abdominal ultrasound and diagnostic aspiration of ascitic fluid. As assessed by Pugh's modification of Child's classification, ${ }^{5}$ eight of these patients were grade $\mathrm{B}$ and seven were grade $\mathrm{C}$. (iii) Cirrhosis without ascites: by Pugh's classification, nine of these patients were grade $\mathrm{A}$ and six grade $\mathrm{B}$. The absence of ascites was confirmed by abdominal ultrasound.

In both groups (ii) and (iii), the presence of cirrhosis was confirmed by liver biopsy. The predominant aetiologies were alcohol and primary biliary cirrhosis. (iv) Severe chronic renal failure: of the 15, eight were receiving haemodialysis and four peritoneal dialysis. In these 12 patients samples were collected before dialysis. (v) Disease controls: all were hospital inpatients. Three patients had congestive cardiac failure, three had acute exacerbations 
Table Plasma albumin, creatinine, alanine aminotransferase $(A L T)$ and prothrombin time ratio $(P T R)$ expressed as medians with ranges in the six groups of subjects

\begin{tabular}{|c|c|c|c|c|c|c|}
\hline & Group 1 & Group 2 & Group 3 & Group 4 & Group 5 & Group 6 \\
\hline Albumin $(\mathrm{g} / \mathrm{l})$ & $\begin{array}{l}41 \\
(38-46)\end{array}$ & $\begin{array}{l}29 \\
(18-36)\end{array}$ & $\begin{array}{l}39 \\
(33-44)\end{array}$ & $\begin{array}{l}37 \\
(32-43)\end{array}$ & $\begin{array}{l}37 \\
(31-45)\end{array}$ & $\begin{array}{l}42 \\
(39-48)\end{array}$ \\
\hline Creatinine $(\mu \mathrm{mol} / \mathrm{l})$ & $\begin{array}{l}106 \\
(78-140)\end{array}$ & $\begin{array}{l}92 \\
(78-117)\end{array}$ & $\begin{array}{l}78 \\
(47-102)\end{array}$ & $\begin{array}{l}1045 \\
(895-1120)\end{array}$ & $\begin{array}{l}82 \\
(52-98)\end{array}$ & $\begin{array}{l}68 \\
(51-79)\end{array}$ \\
\hline $\operatorname{ALT}(\mathrm{IU} / \mathrm{l})$ & $\begin{array}{l}8936 \\
(6194-19165)\end{array}$ & $\begin{array}{l}82 \\
(48-168)\end{array}$ & $\begin{array}{l}50 \\
(31-98)\end{array}$ & $\begin{array}{l}26 \\
(21-33)\end{array}$ & $\begin{array}{l}32 \\
(24-47)\end{array}$ & $\begin{array}{l}23 \\
(19-29)\end{array}$ \\
\hline PTR & $\begin{array}{l}4 \cdot 0 \\
(2 \cdot 7-7 \cdot 3)\end{array}$ & $\begin{array}{l}1 \cdot 6 \\
(1 \cdot 2-2 \cdot 5)\end{array}$ & $\begin{array}{l}1 \cdot 3 \\
(1 \cdot 0-1 \cdot 5)\end{array}$ & $\begin{array}{l}1 \cdot 2 \\
(1 \cdot 0-1 \cdot 4)\end{array}$ & $\begin{array}{l}1 \cdot 2 \\
(1 \cdot 0-1 \cdot 3)\end{array}$ & $\begin{array}{l}1 \cdot 0 \\
(1 \cdot 0-1 \cdot 2)\end{array}$ \\
\hline
\end{tabular}

of asthma, three bacterial pneumonia, three acute or chronic pancreatitis, two untreated coeliac disease and one chronic intestinal pseudo-obstruction. (vi) Fifteen healthy controls.

None of the subjects had had a recent gastrointestinal bleed. There were no significant differences in age between groups (ii)-(vi). Median ages in years with range in these groups were: group (ii) 60 , 37-71; group (iii) 57, 35-74; group (iv) 54, 32-66; group (v) 56, 36-70; group (vi) 60, 30-77. The patients with acute liver disease (group i) were significantly younger (median 22 years, range 18-30, $p<0.001)$ than the other groups. There were no significant differences in sex distribution between any of the groups.

Venous, non-fasting, blood samples were collected from the resting subjects into chilled citric acid containing bottles. ${ }^{2}$ Leucine enkephalin was measured by radioimmunoassay, using antibody, tracer and reagents purchased from Immuno Nuclear Corporation, Stillwater, Minnesota, USA. The assay procedure and its validation, including high performance liquid chromatography, were identical to that previously described for methionine enkephalin.? Within and between assay coefficients of variation were $6 \%$ and $8 \%$. Recovery rate was $79 \%$. Minimum sensitivity was $180 \mathrm{pmol} / \mathrm{l}$. Non-specific binding ranged from $3 \cdot 6-4 \cdot 7 \%$. Cross-reactivity of the antibody was: dynorphin 1-8 6\%, gly-gly-phe-leu $4 \%$, methionine enkephalin $2 \%$, methionine enkephalinarg-phe, methionine enkephalin-arg-gly-leu, dynorphin $1-17$, peptide $E$, peptide $F$ and $\beta$-endorphin all $<0.01 \%$.

Data are expressed as medians with ranges. To convert leucine enkephalin values to $\mathrm{pg} / \mathrm{ml}$, multiply by 0.556 . The statistical significance of differences was determined by the Mann-Whitney $U$ test.

\section{Results}

Plasma leucine enkephalin was considerably raised in all the patients with acute liver disease (median 1490 $\mathrm{pmol} / \mathrm{l}$, range 830-2420) and in the majority of those with cirrhosis and ascites $(960,470-2900)$ compared with those with cirrhosis without ascites (415, $180-620)$, the disease controls $(325,180-740)$ and the healthy controls $(305,180-560)$ (Figure). The peptide's level was slightly increased in the patients with renal failure $(560,180-1020)$ versus the two groups of controls.

In the acute liver disease patients, plasma leucine enkephalin correlated with the prothrombin time $(r=0.691, p<0.01)$ and the alanine aminotransferase $(r=0.502, p<0.05)$ measured in aliquots of the same blood sample. In the patients with cirrhosis (groups ii and iii combined) the peptide's level was negatively correlated with plasma albumin $(r=-0.743, p<0.001)$ but not with the bilirubin, alanine aminotransferase or alkaline phosphatase. It did not correlate significantly with the plasma creatinine in any of the groups with hepatic or renal failure.

Biochemical data regarding the six groups of subjects are shown in the Table.

\section{Discussion}

This study shows that leucine enkephalin is considerably increased in the plasma of patients with cirrhosis, with ascites, and in patients with acute liver disease. The increase is roughly proportional to the degree of liver damage, as judged in the patients with acute liver disease, by the correlation of the peptide's concentration with the alanine aminotransferase and prothrombin time and in the patients with cirrhosis, by the correlation with the plasma albumin. These findings cannot be explained as a non-specific response to illness, as the disease control subjects, some of whom were very ill, had normal plasma levels of the peptide. It seems unlikely that the raised plasma leucine enkephalin in the patients with liver disease is a consequence of leakage from damaged hepatocytes because these cells are a poor source of enkephalins. ${ }^{6-s}$ Furthermore, we found considerably increased plasma levels of the peptide in some of the patients with cirrhosis, many of whom had only 


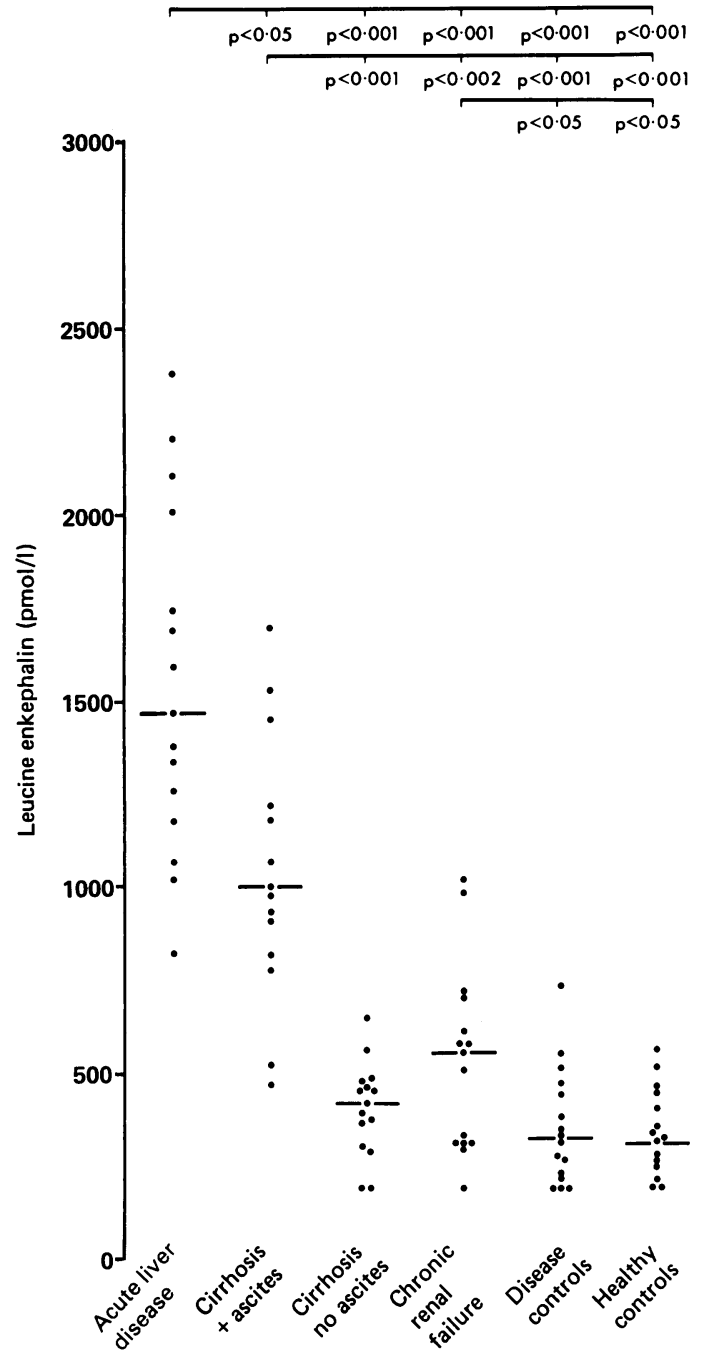

Figure Plasma leucine enkephalin in the six groups of subjects.

modest hepatic inflammation as judged by their alanine aminotransferase.

The origins of plasma leucine enkephalin are unclear. Possible sources are the gut, ${ }^{6910}$ adrenal glands $^{112}$ and sympathetic nerves. ${ }^{13}$

The data do not permit a conclusion as to whether the increased plasma leucine enkephalin is a consequence of diminished hepatic inactivation, increased secretion, or both. Leucine enkephalin is degraded rapidly by a variety of enzymes, ${ }^{1416}$ and the liver contains a high concentration of at least one of these enzymes, leucine aminopeptidase. ${ }^{1718}$ In dogs, the portal venous content of leucine enkephalin was approximately twice that in the hepatic vein. ${ }^{19}$ The suggestion' that the liver enzymatically degrades opioid peptides of octapeptide size or less, such as pentapeptide leucine enkephalin, is consistent with its inactivation of gastrin and cholecystokinin peptides of various chain lengths. Thus, gastrin peptides comprising eight or fewer amino acids and those cholecystokinin peptides with seven or less amino acids were cleared rapidly by the liver, whereas their larger counterparts were much more resistant. ${ }^{2021}$ Adrenal and sympathetic activity are usually raised in severe liver disease, with the exception that, in acute liver disease, sympathetic tone may be normal.22 Therefore, enhanced secretion from the adrenal glands and/or sympathetic nerves may be contributing to the peptide's raised plasma level. The slightly raised level of plasma leucine enkephalin in the patients with chronic renal failure also suggests the possibility that urinary excretion and/or degradation by renal peptidases ${ }^{23}$ may play a minor role in the peptide's elimination.

Compared with a previous similar study, ${ }^{2}$ the present data indicate that leucine enkephalin is approximately six times more plentiful in normal plasma than methionine enkephalin. Both enkephalins are predominantly delta receptor agonists. ${ }^{24}$ Leucine enkephalin's actions include reduction of arterial pressure..$^{3-27}$ Therefore, its raised plasma level in hepatic impairment may contribute to the haemodynamic disturbances of liver disease. If sufficiently sustained, as occurs in the patients with cirrhosis, we suggest that it and other vasodilator opioid peptides such as methionine enkephalin, ${ }^{2}$ may promote the development of portal hypertension and ascites by stimulating increased sympathetic nervous tone. ${ }^{2222829}$

These data were presented to the Autumn meeting of the British Society of Gastroenterology, 1988. We thank the Mason Medical Research Foundation for financial support, Mrs S Shires for technical assistance and Drs A Davison and E Will for allowing us to study the patients with renal failure.

\section{References}

1 Thornton JR, Losowsky MS. Methionine enkephalin is increased in plasma in acute liver disease and is present in bile and urine. J Hepatol 1989; 8: 53-9.

2 Thornton JR, Dean H, Losowsky MS. Is ascites caused by impaired hepatic inactivation of blood-borne endogenous opioid peptides? Gut 1988; 29: 1167-72.

3 Thornton JR, Losowsky MS. A role for the kidneys and liver in plasma beta-endorphin elimination? Clin Sci 1988; 74 [suppl 18]: 51P. 
4 Thornton JR, Losowsky MS. Opioid peptides and primary biliary cirrhosis. Br Med J 1988; 297: 1501-4.

5 Pugh RNH, Murray-Lyon IM, Dawson JL, Pietroni MC, Williams R. Transection of the oesophagus for bleeding oesophageal varices. Br J Surg 1973; 60: 646-9.

6 Hughes J, Kosterlitz HW, Smith TW. The distribution of methionine-enkephalin and leucine enkephalin in the brain and peripheral tissues. Br J Pharmacol 1977; 61: 639-47.

7 Tang J, Yang H-YT, Costa E. Distribution of met ${ }^{5}-$ enkephalin-arg'-phe (MEAP) in various tissues of rats and guinea pigs. Life Sci 1982; 31: 2303-6.

8 Farrell LD, Harrison TS, Demers LM. Immunoreactive met-enkephalin in the canine adrenal; response to acute hypovolemic stress. Proc Soc Exp Biol Med 1983; 173: 515-8.

9 Sakamoto M, Nakao K, Yoshimasa T, et al. Occurrence of methionine-enkephalin-arg'-gly -lcu $^{\mathrm{x}}$ with methionine-enkephalin, leucine-enkephalin and methionine-enkephalin-arg ${ }^{6}-$ phe $^{7}$ in human gastric antrum. J Clin Endocrinol Metab 1983; 56: 202-4.

10 Feurle GE, Helmstaedter V, Weber U. Met- and leuenkephalin immuno- and bio-reactivity in human stomach and pancreas. Life Sci 1982; 31: 2961-9.

11 Viveros OH, Dilberto EJ, Hazum E, Chang K-J. Opiate-like materials in the adrenal medulla: evidence for storage and secretion with catecholamines. Mol Pharmacol 1979; 16: 1101-8.

12 Livett BG, Dean DM, Whelan LG, Udenfriend S, Rossier J. Co-release of enkephalin and catecholamines from cultured adrenal chromaffin cells. Nature 1981; 289: 317-8.

13 Schultzberg M, Hokfelt T. Lundberg JM. Terenius L. Elfvin LG, Elde R. Enkephalin-like immunoreactivity in nerve terminals in sympathetic ganglia and adrenal medulla and in adrenal medullary gland cells. Acta Physiol Scand 1978; 103: 475-7.

14 Hughes J. Isolation of an endogenous compound from the brain with pharmacological properties similar to morphine. Brain Res 1975; 88: 295-308.

15 Hersh LB. Reaction of opioid peptides with neutral endopeptidase ('enkephalinase'). J Neurochem 1984; 43: 487-93.

16 Roscetti G, Possenti R, Bassano E, Roda LG. Mechanisms of leu-enkephalin hydrolysis in human plasma. Neurochem Res 1985; 10: 1393-404.
17 Nachlas MM. Crawford DT. Seligman AM. Histochemical demonstration of leucine aminopeptidase. J Histochem Cytochem 1957; 5: 264-78.

18 Rutenberg AM, Goldberg JA, Pineda EP. Leucine aminopeptidase activity. Observations in patients with cancer of the pancreas and other diseases. N Engl J Med 1958; 259: 469-72.

19 Laasberg LH, Johnson EE, Hedley-White J. Effect of morphine and naloxone on leu-enkephalin-like immunoreactivity in dogs. J Pharmacol Exp Ther 1980; 212: $496-502$.

20 Strunz UT, Thompson MR, Elashoff J, Grossman MI. Hepatic inactivation of gastrins of various chain lengths in dogs. Gastroenterology 1978; 74: 550-53.

21 Doyle JW, Wolfe MM, McGuigan JE. Hepatic clearance of gastrin and cholecystokinin peptides. Gastroenterology 1984; 87: 60-8.

22 Thornton JR, Dean HG, Losowsky MS. Do increased catecholamines and plasma methionine enkephalin in cirrhosis promote bleeding oesophageal varices? $Q J$ Med 1988; 68: 541-51.

23 Malfroy B, Schwartz JC. Purification and substrate specificity of rat kidney 'enkephalinase'. Life Sci 1982; 31: $1745-8$.

24 Grossman A, Clement-Jones V. Opiate receptors: enkephalins and endorphins. Clin Endocrinol Metab 1983; 12: 31-56.

25 Schaz K, Stock G, Simon W, et al. Enkephalin effect on blood pressure, heart rate and baroreceptor reflex. Hypertension 1980; 2: 395-407.

26 Hanbauer I, Kelley GD, Saiani L, Yang HYT. [Met ${ }^{\varsigma}$ ]enkephalin-like peptides of the adrenal medulla: release by nerve stimulation and functional implications. Peptides 1982; 3: 469-73.

27 Szabo B, Hedler L, Ensinger J, Starke K. Opioid peptides decrease noradrenaline release and blood pressure in the rabbit at peripheral receptors. Naunyn-Schmiedeberg's Arch Pharmacol 1986; 332: $50-6$.

28 Willett IR, Esler M, Jennings G, Dudley FJ. Sympathetic tone modulates portal venous pressure in alcoholic cirrhosis. Lancet 1986; ii: 939-43.

29 Moreau R, Lee SS, Hadengue A, Braillon A, Lebrec D. Hemodynamic effects of a clonidine-induced decrease in sympathetic tone in patients with cirrhosis. Hepatology 1987; 7: 149-54. 